\title{
複合格子シーラント層による自己修復タイヤの開発と振動解析*
}

\author{
金哲 紅*1, 三 輪卓*1 \\ 陳志超*1, 長 屋 幸 助*2
}

\section{Self-repairing Tire Using Composite Lattice Sealant Layer and Its Vibration Analysis}

\author{
Zhehong JIN, Suguru MIWA, Zhichao CHEN and Kosuke NAGAYA*3 \\ *3 Department of Mechanical Engineering. Gunma University, \\ 1-5-1 Tenjincho, Kiryu-shi, Gunma, 376-8515 Japan
}

\begin{abstract}
The new sealant layer is presented, which is easier to include into the manufacture process of the tire in comparison with the previous research. The performance of the present tire was investigated, and it was clarified that there was no air leak when nails broke it. Vibration characteristics of the present tire were analyzed theoretically and experimentally, and the effects of the sealant on the road-ability and the road noise were investigated. Using the analysis, it is shown that vibration transmissibility decreases in the present. The impact characteristics are also discussed. The transmissibility is also decrease when the impact load applies to the tire, and load noise is also decreased.
\end{abstract}

Key Words: Tire, Non-puncture, Sealant, Self-repairing, Vibration, Analysis, Transmissibility, Damping

\section{1. 緒言}

近年, タイヤの安全性確保のため, 空気圧を自動的 に測定し送信するシステム(1), タイヤの圧力を安全に 保つように, 空気を送り続ける装置を取付ける方法 ${ }^{2}$ など、タイヤの安全性をメンテナンスで保持する方法 が提案されている。また，二輪車ではあるが，チュー ブのトレッドとショルダ部分を空気室と液室の二重構 造とし, 特殊なパンク防止液を液室に製造段階で封入 する構造のもの ${ }^{(3)}$, 二重構造のチューブ(4) が提案され ている. 一方, 空気漏れを起こしてもある程度の距離 を走行できるランフラットタイヤも開発された.この タイヤは, タイヤとリムの間に特殊なメタルリングの 装着、タイヤ側面の補強等をし, 空気が完全に抜けて しまっても車の重量を支えられるようにしたものであ る.しかし、この方法でもある程度走行後はパンク修 理が必要である。

上記のタイヤで，もしパンクしても即座にパンク穴 を自己修復することができれば，パンク修理も必要な

\footnotetext{
* 原稿受付 2005 年 8 月 4 日

*1 群馬大学大学院工学研究科(亚376-8515 桐生市天神町 1-5 1).

*2 正員. 群馬大学工学部.

E-mail : nagaya $@$ me.gunma-u.ac.jp
}

く,また自己修復するシステムが軽い弾性に富む材料 でできていれば, エネルギーロスも小さく, 乗り心地 もほとんど通常のタイヤと変わらなくできるはずであ る.このような観点から長屋ら ${ }^{(5)}$ は吸水ポリマを用 いた自己修復夕イヤを開発し, 上記ランフラットタイ ヤよりはるかに優れていることを確認した。しかしこ の研究では, シーラント層の作成にオートメーション 化を行うときの製造上の問題があると同時に, 走行安 定性についての検討が全くなされていなかった。そこ で本研究では, 前研究よりさらにタイヤの製造過程に 組込みやすいシーラント層の開発を行うとともに，パ ンクレスタイヤの振動特性の解析をも行い, 本夕イヤ の走行安定性に与える影響を明らかにする.

\section{2. 複合格子シーラント層の開発}

本タイヤは，穴があいても自己修復するシーラント 層をタイヤ内面に張り付ける。このシーラント層は吸 水ポリマを膨潤液で膨潤させ，格子ブロック内にその 膨潤圧を閉じこめたものである。この格子を作るため に, 前報(5) ではキルティングを行ってシーラント層に 格子を作っていた。しかし，この方法は大量生産には 向かない.そこで本研究では，あらかじめ格子を有す るシートを作り，その中に吸水ポリマを充てんし，そ 
の上下面にカバーシートを接着することを考える。し かしこの方法では, 格子部分にくぎが刺さった場合に 自己修復機能がなくなる，そこで, シーラントのどの ような位置にくぎが刺さっても吸水ポリマ層を貫通す るような格子配置を考えた。

図 1 はその配置を示したもので, 図の上に示した 2 枚の格子付き(白い部分が格子線)シート $(2,3)$ を互い にずらせて接着し，格子の中に吸水ポリマを充てんし， 上下面にカバーシート $(1,4)$ を接着する. 図 1 で格子 部分の重なりがないので, どの位置にくぎを刺しても ポリマ層をくぎが貫通することがわかる，生ゴムのシ 一トを用いて上記のような配置を行い, 格子内にポリ マを充てんした後, 上下のカバーシートの上から圧縮 すると,カバーシートと格子は一体となって接着した 状態となる。このシーラント層の格子内に膨潤液を充 てんする必要があるが, 膨潤液については, エチレン グリコール(自動車用クーラント液) と水を $8: 2$ で混 合したものが適当であることがわかった。この膨潤液 を用いるとポリマの膨潤が得られ，タイヤ使用中の温 度上昇 (最大約 $90^{\circ} \mathrm{C}$ ) に対しても安全で, また寒冷地の 凍結防止 $\left(-40^{\circ} \mathrm{C}\right)$ もできる.

あらかじめ膨潤液で膨張したポリマを格子内に充て んしたのでは, 膨潤圧を格子内に閉じこめることがで きないので, 格子内にポリマを充てんした後に膨潤液 を注入する必要がある，前報ではこれを注射器を用い て行っていたが,これでは工場生産に適さない。そこ で, 上記シーラント層のカバーシートに穴をあけ,こ

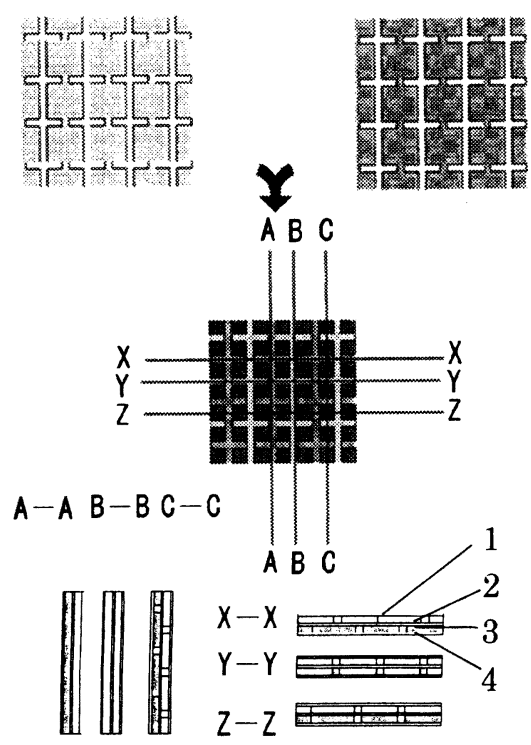

Fig. 1 Lattice setting for the sealant
れを膨潤液で満たされたタンク内にドブ漬けし, タン クに圧力を与えて強制的に膨潤液を格子内に注入する 方法を試みた。その結果, タンク内圧力に最適值があ り, $0.6 \mathrm{MPa}$ のとき最も膨潤液が格子内に入りやす いことを確認した。また, 加圧時間 2 時間程度で膨潤 液を格子内に十分注入することができた。膨潤液を注 入すると格子内のポリマが膨潤するため, カバーシー トが大きく膨らむ。この膨らみを取り去るため, シー ラント層を平板の間に挟み再度圧縮したところ, 平滑 な面を得ることができた。これは, 吸水ポリマに水分 を与えて圧縮すると粘着力を発現するためで, 凹凸の ある面を圧縮することで, 膨潤圧とポリマどうしの接 着力が釣合って膨潤圧を格子内に閉じこめたままで平 滑な面が得られたものである. 前報では, タイヤ内面 に凸凹ができ走行安定性に問題があったが，このよう な方法でその欠点を解消できた。

上記のようにして作成したシーラント層の性能を調 べるため, 空気漏えい試験を行った。用いた実験装置 および実験方法は前報(5) と同様である。まず，格子線 以外のところにくぎを刺して引抜いた場合, 吸水ポリ マの厚さが $4 \mathrm{~mm}$ 以上であれば, くぎ直径が $5.2 \mathrm{~mm}$ （五寸くぎ）でも全く空気漏れはなかった。一方格子線 上にくぎが刺さった場合はポリマ層が半分になるの で、ここが最も空気漏れに弱い部分となる，そこで， 格子線上にくぎを刺したときの実験を行った。図 2 が その結果で, 白丸印がポりマ層厚が $2 \mathrm{~mm}$ のとき, 白 三角印が $3 \mathrm{~mm}$ のとき, 白四角印が $4 \mathrm{~mm}$ のときをそ れぞれ表す. 図 20 縦軸は実験容器内空気圧で, 空気 漏れがあると圧力が低下するので, 圧力の低下がなけ れば空気漏えいがないことになる。ポリマ層厚が 2 $\mathrm{mm}$ と $3 \mathrm{~mm}$ では空気漏れのため圧力が低下してい るが, ポリマ層厚が $4 \mathrm{~mm}$ 以上では空気漏れがないこ とがわかる。

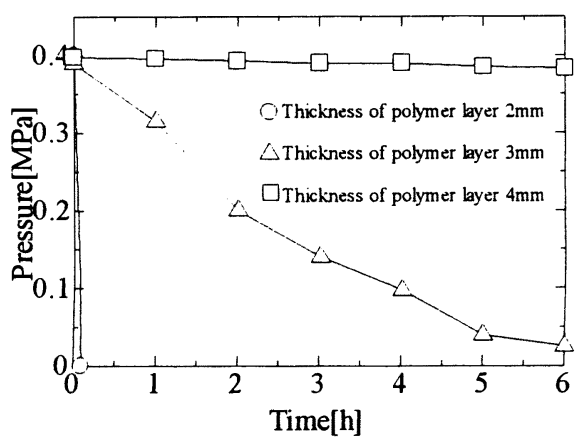

Fig. 2 Leak test for our tire when the tire is broken by a nail of $5.2 \mathrm{~mm}$ in diameter 


\section{3. 自己修復タイヤの振動伝達率の解析}

タイヤの振動解析は弾性円環モデルを用いて, $\mathrm{Bohm}^{(6)}$ により行われている.しかしその解析では夕 イヤのゴムを完全弾性体として扱っており, また自由 振動を解析しているので, 固有振動数しか求めること ができない.タイヤの振動を評価する場合, タイヤ表 面に外力が作用したときに車軸に作用する振動が車体 へ伝えられ，車体の振動あるいはロードノイズ(騒音) となるため, 振動伝達率が重要である.しかしこの問 題に対する研究はほとんどが実験的研究であり(7) (9), 解析的な研究はいまだ十分になされていないように見 受けられる. 本研究では開発した自己修復夕イヤの振 動伝達特性, 特に伝達率に及ぼすシーラント層の影響 を解析する.

$3 \cdot 1$ 格間・格点マトリックス $\mathrm{Bohm}^{(6)}$ およ゙ その後の夕イヤの研究(7) (9) では, 夕イヤ表面層を円 環とみなし，側面部を半径方向および周方向のばねで 近似する方法が一般的に用いられている (図 3 参照). ここで, $k_{x}$ は半径方向のばね定数, $k_{z}$ は周方向のばね 定数であり, $E\left[=E_{0}(1+i \eta)\right]$ は夕イヤ表面層の減衰 を考慮した複素弾性率, $E_{0}$ は縦弾性係数, $\eta$ は損失係 数, $\rho$ は夕イヤの周方向に沿う線密度, $A$ は円環の断 面積, および $\Omega$ はホイールの回転角速度である.夕 イヤ表面層は夕イヤ内圧により周方向に張力が発生し ている。この張力を $T_{0}$ とする. タイヤ表面層を周方 向に角度 $\phi$ の曲りばり要素に分割し, 中心角を $\phi$, 曲 りばりの軸方向長さを $s$ とし, 図 4 のような座標を考 え, $y$ 軸を $x-z$ 面に垂直にとる.

この曲りばりに対する釣合い方程式は

$$
\frac{\partial U}{\partial s}-k V=0 \quad \cdots \cdots \cdots \cdots \cdots \cdots \cdots \cdots \cdots \cdots \cdots \cdots \cdots \cdots \cdots \cdots \cdots \cdots \cdots
$$

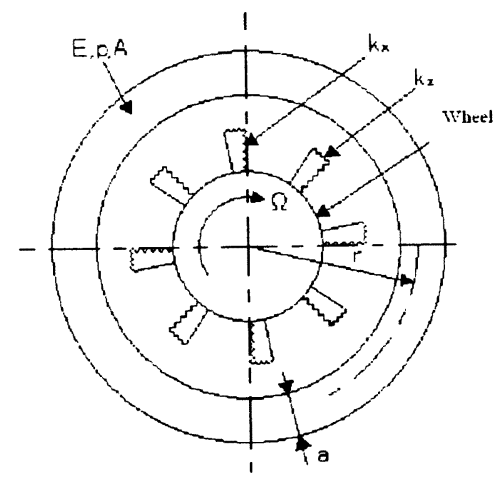

Fig. 3 Tire model

$$
\begin{aligned}
& \frac{\partial V}{\partial s}+k U-T_{0} \frac{\partial^{2} v}{\partial s^{2}}=0 \cdots \cdots \cdots \cdots \cdots \cdots \cdots \cdots(1 \cdot \mathbf{b}) \\
& \frac{\partial M}{\partial s}+V=0 \cdots \cdots \cdots \cdots \cdots \cdots \cdots \cdots \cdots \cdots \cdots \cdots \cdots \cdots \cdots \cdots \cdots \cdots \cdots \cdots \cdots \cdots \cdots \cdots \\
& (1 \cdot \mathbf{c})
\end{aligned}
$$

ここに $V, U$ は断面力の $x, z$ 成分, $M$ は $y$ 軸まわり の断面モーメントであり, $k$ は中心線での曲率であ る、また，この要素の中心軸まわりの角座標を $\phi$ とす ると,

$$
\frac{\partial s}{\partial \phi}=R
$$

ただし， $R(=1 / k)$ は曲率半径である一方, 断面力と断 面モーメントは変位, 角変位を用いて

$$
\left.\begin{array}{l}
U=E A\left(\frac{\partial u}{\partial s}-k v\right) \\
M=E I_{y}\left(\frac{\partial^{2} v}{\partial s^{2}}+k \frac{\partial u}{\partial s}\right) \\
\psi=\frac{\partial v}{\partial s}+k u
\end{array}\right\}
$$

ここに $v$ は $x$ 方向変位, $u$ は $z$ 方向変位であり, $\psi$ は はり断面の回転角の $y$ 成分 $(y$ 軸まわり)である。 ま た, $I_{y}$ は $y$ 軸に関する断面二次モーメントである。 式（1 ）（ 3 ) より変位 $u, v$ についまとめると

$$
\left.\begin{array}{l}
\frac{\partial^{3} u}{\partial \phi^{3}}+\frac{\partial u}{\partial \phi}-\left(T_{0}^{*}+1\right) \frac{\partial^{2} v}{\partial \phi^{2}}-v=0 \\
\left(1+S^{2}\right) \frac{\partial^{2} u}{\partial \phi^{2}}+\frac{\partial^{3} v}{\partial \phi^{3}}-S^{2} \frac{\partial v}{\partial \phi}=0
\end{array}\right\}
$$

ここに

$$
T_{0}^{*}=\frac{T_{0} R^{2}}{E I_{y} S^{2}}, \quad S=\sqrt{\frac{A R^{2}}{I_{y}}}
$$

式 (4)を解き，これを式(1)〜（3)に代入しすべて の解を求め, マトリックス形にまとめると,

$$
\{X)=[b]\{a\}
$$
ここに

$$
\begin{aligned}
& \{X\}=\left[\begin{array}{lllllll}
u^{*} & v^{*} & \psi^{*} & U^{*} & V^{*} & M^{*} & 1
\end{array}\right]^{T} \\
& u^{*}=u / \Delta, \quad v^{*}=v / \Delta, \quad \phi^{*}=R_{0} \psi / \Delta
\end{aligned}
$$

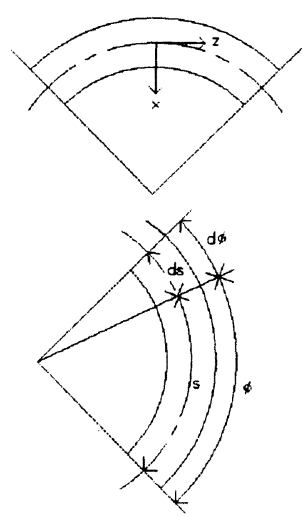

Fig. 4 Coordinate for the ring element 


$$
\begin{aligned}
& U^{*}=R_{0}^{3} U /\left(E_{0} I_{y} \Delta\right) \\
& V^{*}=R_{0}^{3} V /\left(E_{0} I_{y} \Delta\right), \quad M^{*}=R_{0}^{2} M /\left(E_{0} I_{y} \Delta\right)
\end{aligned}
$$

また, $\{a\}=\left\{A_{1} A_{2} \cdots A_{6}\right\}^{T}$ は係数べクトルであり, $R_{0}$ は夕イヤの初期半径であり， $R$ は車体の荷重を受けつ ぶれたときの夕イヤの各要素の点における半径, $\Delta$ は 変位を無次元化するための基準長さである. なお，解 マトリックスの要素 $b$ は付録に示される。

いま $j$ 番めのはり要素を考え, 解マトリックス $[b]$ より格間マトリックスを求めると,

$[F]_{i}=\left[b\left(\phi_{i}\right)\right][b(0)]^{-1}$

一方 $x, z$ 方向の弾性力を考慮し, 格点に質量を分 布させ，その格点をばね定数 $k_{x}, k_{z}$ のばねで支持する とすれば, 質点の左 $(L)$, 右 $(R)$ の釣合い式は

$$
\left.\begin{array}{l}
u_{i}^{R}=u_{i}^{L}, \quad v_{i}^{R}=v_{i}^{L}, \quad \phi_{i}^{R}=\psi_{i}^{L} \\
U_{i}^{R}=U_{i}^{L}+m_{i}\left(\frac{\partial^{2} u}{\partial t^{2}}\right)_{i}^{L}+k_{z i} u_{i}^{L}+C_{z i}\left(\frac{\partial u}{\partial t}\right)_{i}^{L} \\
V_{i}^{R}=V_{i}^{L}+m_{i}\left(\frac{\partial^{2} v}{\partial t^{2}}\right)_{i}^{L}+k_{x i} V_{i}^{L}+C_{x i}\left(\frac{\partial v}{\partial t}\right)_{i}^{L} \\
M_{i}^{R}=M_{i}^{L}
\end{array}\right\}
$$

ここに, $m_{i}$ は格点 $i$ の質量を, $k_{x i}, k_{z i}$ は格点のばね 定数を, $C_{x i}, C_{z i}$ は空気減衰および夕イヤ側面部の減 衰を格点においたときの減衰係数を表す。一方点 $\mathrm{q}$ を加振点とし， $Q$ の振動荷重がタイヤに垂直に作用す るとしたとき，その点の釣合い式は

$$
\left.\begin{array}{l}
U_{q}^{R}=U_{q}^{L}+m_{q}\left(\frac{\partial^{2} u}{\partial t^{2}}\right)_{q}^{L}+k_{z q} u_{q}^{L}+C_{z q}\left(\frac{\partial u}{\partial t}\right)_{q}^{L} \\
V_{q}^{R}=V_{q}^{L}+m_{q}\left(\frac{\partial^{2} v}{\partial t^{2}}\right)_{q}^{L}+k_{x q} v_{q}^{L}+C_{x q}\left(\frac{\partial v}{\partial t}\right)_{q}^{L}+Q
\end{array}\right\}
$$

式( 5 )を式( 7 )，（8)に代入すると次式が得られる.

$$
\{X\}_{i}^{R}=\left[P_{i}\right]\{X\}_{i}^{L}
$$

ここに格点マトリックス $\left[P_{i}\right]$ の要素は

$$
\begin{aligned}
& p_{n n}=1(n=1,2, \cdots 7), \quad p_{41}=\gamma_{z}, \quad p_{52}=\gamma_{x} \\
& p_{57}=Q^{*} \cdots \cdots \cdots \cdots \cdots \cdots \cdots \cdots \cdots \cdots \cdots \cdots \cdots \cdots \cdots \cdots \cdots \cdots \cdots \cdots \cdots \cdots \cdots
\end{aligned}
$$

であり,他の要素は零である。また

$$
\begin{aligned}
\gamma_{x} & =\frac{-R_{0}^{3} m_{i} \Omega^{2}}{E_{0} I}+\frac{R_{0}^{3} k_{x i}}{E_{0} I}+\frac{R_{0}^{3} j \Omega C_{x i}}{E_{0} I} \\
\gamma_{z} & =\frac{-R_{0}^{3} m_{i} \Omega^{2}}{E_{0} I}+\frac{R_{0}^{3} k_{z i}}{E_{0} I}+\frac{R_{0}^{3} j \Omega C_{z i}}{E_{0} I} \\
Q^{*} & =\frac{R_{0}^{3} Q}{E_{0} I \Delta}
\end{aligned}
$$

上式で $j=\sqrt{-1}$ であり, 質量, ばね定数, 減衰係数 は点 $i$ の分割長に対するものである。いま夕イヤ周方 向単位長さ当たりの $k_{x}, k_{z}, C_{x}, C_{z}$ を用いると, $k_{x i}$ $=R_{0} \phi k_{x}, k_{z i}=R_{0} \phi k_{z}, C_{x i}=R_{0} \phi C_{x}, C_{z i}=R_{0} \phi C_{z}, m_{i}$ $=R_{0} \phi m$ となる.また, 荷重のない点では, $Q^{*}=0$ と おけばよい.

\section{$3 \cdot 2$ 境界条件 任意点 $i$ の状態量は}

$\{X\}_{i}=[T]_{i}\{X\}_{0}$

ここに

$[T]_{i}=[F]_{i}[P]_{i-1}[F]_{i-1} \cdots \cdots[P]_{1}[F]_{1}$

はりを点 0 から点 $\mathrm{N}$ まで $N$ 分割したとき，点 $\mathrm{N} の$ 状態量と点 0 の状態量は等しいので

$$
\begin{aligned}
& \{X\}_{N}=\{X\}_{0} \ldots \ldots . . \\
& \{X\}_{N}=[T]_{N}\{X\}_{0}
\end{aligned}
$$

となる。 $[T]_{N}$ は式(12)より計算され,この要素を $a_{k g}$ とおくと, 式 $(13 \cdot \mathrm{a})$ および $(13 \cdot \mathrm{b})$ より

$\left\{[T]_{N}-[I]\right\}\{X\}_{0}=-\left\{A_{7}\right\}$

ここに $[I]$ は単位マトリックスであり, $\left\{A_{i}\right\}=-\left[a_{17}\right.$ $\left.\begin{array}{lllll}a_{27} & a_{37} & a_{47} & a_{57} & a_{67}\end{array}\right]^{T}$ である. 式(14)より $\{X\}_{0}$ を求 め, これを式(11)に代入すると任意点 $i$ の応答が求め られる。

$3 \cdot 3$ 振動伝達率 荷重点を曲りばり要素の始点 0にとり, タイヤ面に振動荷重が作用したとき，ハブ の $\gamma$ 方向 (図 5 参照)に作用する要素 $i$ の復元力 $W_{i}$ は

$$
W_{i}=v_{i} k_{x i} \cos \theta_{i}+u_{i} k_{z i} \sin \theta_{i}
$$

荷重 $Q$ と伝達率の方向を同じにとると荷重は $\gamma$ 軸 と対称となるので, 伝達率 $\tau$ は

$$
\tau=\frac{2}{Q} \sum_{i=1}^{N / 2} v_{i}^{*} k_{x i} \Delta \cos \theta_{i} \cdots
$$

減衰を考慮したとき, $\tau$ は複素数となるが, その振 幅 $\tau^{*}$ と位相 $\varepsilon$ は

$$
\tau^{*}=\sqrt{\tau_{R}^{2}+\tau_{I}^{2}}, \quad \tan (\varepsilon)=\tau_{I} / \tau_{R}
$$

であり， $\tau_{R}$ は $\tau$ の実部を $\tau_{I}$ は虚部を表す.

夕イヤの自由振動については, Bohm ${ }^{(6)}$ の解析があ る. 本数值計算では，まずBohmのモデルに対し本 解析を適用し，固有振動数に対する誤差を検討してみ た。数值計算に用いたデー夕はBohmのものを SI 単 位に換算した次の諸量を用いた。すなわち, タイヤ半 径 $R_{0}=0.273 \mathrm{~m}$, 夕イヤ幅 $b=0.075 \mathrm{~m}$, 夕イヤ厚 $d$ $=0.0018 \mathrm{~m}$, 周方向単位長さ当たりのばね定数 $k_{z}=$ $3.55 \times 10^{5}\left[\mathrm{~N} / \mathrm{m}^{2}\right]$ ，半径方向単位長さ当たりのばね定 数 $k_{x}=1.27 \times 10^{5}\left[\mathrm{~N} / \mathrm{m}^{2}\right]$, 張力 $T_{0}=1911 \mathrm{~N}, E I_{y}=$ $0.0692 \mathrm{~N} \cdot \mathrm{m}^{2}, \rho=1.558 \mathrm{~kg} / \mathrm{m}$. 分割数を 300 とした ときの本解析と Bohm の結果との比較を表 1 に示す. 表 1 より本解析の固有振動数とBohmの結果はほぼ 一致しており, 本解析が妥当な結果を与えていること がわかる。

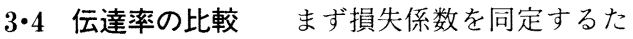
め, 実際のタイヤのトレッド部(路面に接する部分)を 切り取り,片持ばりとして自由振動を行わせ, 固有振 動数と減衰波形から縦弾性係数と損失係数を実験的に 同定した.このときの試験片の長さは $180 \mathrm{~mm}$, 幅は 
$52.5 \mathrm{~mm}$ である。数值計算に用いる諸量は夕イヤの トレッド部は自由振動実験で得られたものを用い, 他 の諸量は Bohm(6) のものと同じとする.すなわち

$$
\begin{aligned}
\text { ( a ) ノーマルタイヤの場合 } \\
R_{0}=0.273 \mathrm{~m}, \quad b=0.075 \mathrm{~m} \\
d=0.0105 \mathrm{~m}, \quad A=0.000788 \mathrm{~m}^{2} \\
k_{a}=3.55 \times 10^{5}\left[\mathrm{~N} / \mathrm{m}^{2}\right], \quad k_{\tau}=1.27 \times 10^{5}\left[\mathrm{~N} / \mathrm{m}^{2}\right] \\
T_{0}=1911 \mathrm{~N}, \quad E_{0} I_{y}=0.329 \mathrm{~N} \cdot \mathrm{m}^{2} \\
\rho^{*}=1.150 \mathrm{~kg} / \mathrm{m}, \quad \eta=0.24
\end{aligned}
$$

（b）本自己修復夕イヤの場合 $d=0.0205 \mathrm{~m}, \quad A=0.00153 \mathrm{~m}^{2}$ $E_{0} I_{y}=0.357 \mathrm{~N} \cdot \mathrm{m}^{2}$

$\rho^{*}=2.03 \mathrm{~kg} / \mathrm{m}, \quad \eta=0.3$

なお, 上記のばね定数は周方向単位長さ当たりの値 である，他の諸量は ( a )ノーマルタイヤの場合と同様 である、数值計算では夕イヤに初期変形がないとし $\left(R=R_{0}\right), \Delta=1$ として計算を行った。図 6 は本自己 修復夕イヤとノーマルタイヤの伝達率の比較を行った ものであり，実線が本タイヤの結果を，破線はノーマ ルタイヤの結果である。本数值計算ではシーラント層 の厚さを $10 \mathrm{~mm}$ として計算しているため, 質量が， ーマルタイヤより大きくなっている.そのため, 固有 振動数が低下している. しかし，その分減衰の作用も 大きくなっており, 第一次のピークはノーマルタイヤ に比べかなり減少している。このときのタイヤの危険 速度は約 $330 \mathrm{~km} / \mathrm{h}\left(v_{c}=54 \times 3600 \times 2 \pi \times 0.273 / 1000\right.$ $=333 \mathrm{~km} / \mathrm{h})$ であり, 通常のタイヤの走行速度より大 きいことから, シーラント層を最大 $1 \mathrm{~cm}$ 厚程度まで としても, 走行中にタイヤの共振は起こらないと思わ れる。実際にはシーラント層の厚みは $6 \mathrm{~mm}$ 程度と

Table 1 Comparison between present and Bohm's frequencies $f[\mathrm{~Hz}]$

\begin{tabular}{|l|l|l|l|l|}
\hline Mode & 1 & 2 & 3 & 4 \\
\hline Present & 81 & 91 & 129 & 134 \\
\hline Bohm & 83 & 98.5 & 115 & 136 \\
\hline
\end{tabular}

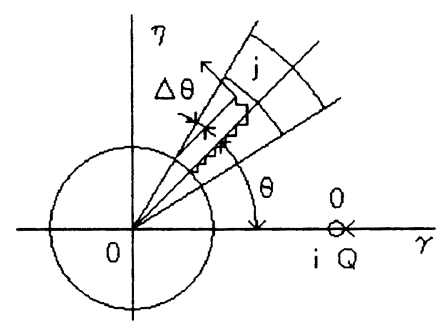

Fig. 5 Model for obtaining transmissibility
してよいし, また現在のタイヤはタイヤ空気圧が乗用 車で $p=0.2 \sim 0.25 \mathrm{MPa}$, トラックで $p=0.4 \mathrm{MPa}$ と, Bohm の空気圧 $p=0.12 \mathrm{MPa}$ よりなり大きいこと から, 危険走行速度は上記より相当大きくなるため (後述), シーラント層の質量増加による固有振動数の 低下は問題にならないと考えられる.なお, 本解析の 伝達率は夕イヤの振動変位による復元力を全周積分で 求められるので, 変位の小さいところで計算誤差が生 じる.図 6 で $60 \mathrm{~Hz}$ 近傍に見られるピークは計算誤 差であり, また変位の小さい高次の伝達率の計算では 誤差が大きくなるようであり，二次を超える振動数に 対する伝達率はプロットしていない.

\section{4. パンクレスタイヤを用いた系の 衝撃減衰特性}

タイヤに求められる動的性能としては, 上記の共振 の次にバランシングがとれていることであるが, これ について本タイヤは製造が複雑であるので, 通常夕イ ヤよりアンバランスが大きいと考えられる。しかし, 回転バランスはほぼ完全に釣合い錘でとることができ る。一方, タイヤは緩衝装置の一部として用いられて いるので, 突起乗越し時の振動減衰特性も重要であ る. 突起乗越しの振動減衰は, 自動車の場合サスペン ションがその機能を担っているわけであるが，タイヤ の減衰効果が大きければ，もちろん車体の振動抑制効 果も大きくなる、そこで, 以下本タイヤによる車体へ の振動抑制効果をモデルを用いて検討する.

$4 \cdot 1$ 衝撃応答 タイヤはサスペンションを介し て車体に接続されており, サスペンションと車体の系 は夕イヤの固有振動数よりかなり低く作られている. したがって, 本タイヤの衝撃を受けるときの減衰の影 響を調べるため, 図 7 のような簡単な実験装置を作成 し, 本タイヤが接続された場合の系の衝撃応答特性を

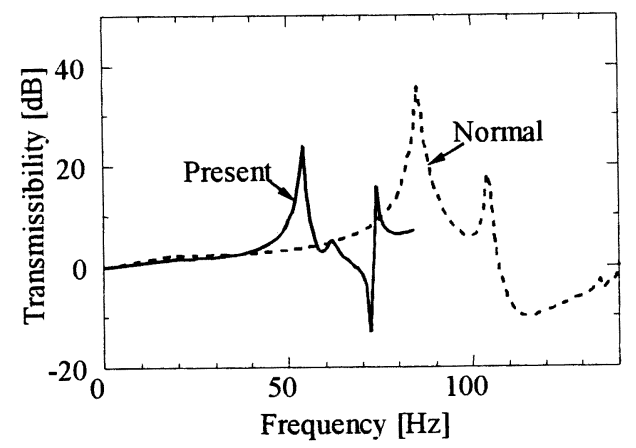

Fig. 6 Comparison of transmissibility between the present and normal tires 
調べる.

図 7 では, タイヤのホイールをアルミ板に 4 本のボ ルトで固定し，アルミ板の上部をつるしてある.アル ミ板の上部を細く削り取って剛性を低下させ, サスペ ンションを模擬した。その部分にひずみゲージを張り 付け, 鋼球をタイヤの真上に落下させるようにした。 そして, 系のバランスを保つためバランス棒を付けて ある.この系では夕イヤ, ホイールおよびバランス棒 が質量となり，アルミ板の細い部分がばねとなってお り,これによりばね質量系を構成している.夕イヤ上 面に落下させる鋼球によりタイヤに衝撃荷重を与え, ひずみゲージのひずみを測定することで, タイヤを通 してホイールに伝達された振動荷重が測定される。

本実験に用いたタイヤは市販のものであり, 前述の 計算のものとは異なる。その諸元は下記のとおりであ る.すなわち, ノーマルタイヤ(シーラント層なし)質 量: $7.8 \mathrm{~kg}$, パンクレスタイヤ質量： $10.3 \mathrm{~kg}$ (シーラ ント層の厚みは約 $6 \mathrm{~mm}$ ), ノーマルシステムの全質 量: $18.2 \mathrm{~kg}$, パンクレスシステムの全質量 : $20.7 \mathrm{~kg}$, ホイール半径: $0.363 \mathrm{~m}$, ホイール重量: $5.9 \mathrm{~kg}$, 夕 イヤ外半径 : $0.29 \mathrm{~m}$, 夕イヤ内半径 : $0.16 \mathrm{~m}$, 夕イヤ 幅： $0.155 \mathrm{~m}$, タイヤ内圧：0.24 MPa，ひずみ測定部 の断面積: $24 \mathrm{~cm}^{2}$, ひずみ測定部の有効長さ $: 0.8 \mathrm{~m}$, ひずみ測定用鋼板質量： $4.5 \mathrm{~kg}$, 鋼球の落下高さ： $0.81 \mathrm{~m}$, 鋼球の質量： $0.108 \mathrm{~kg}$ である. 測定に用い たひずみゲージの荷重 $P$ とひずみ $\varepsilon$ 関係を $P=k \varepsilon$ としたときの係数の值は, $k=1.92 \mathrm{~N} / \mathrm{V}$ となっい る.

図 8 はパンクレスの施されていない通常のタイヤに 上記の鉄球を落下させたときの時刻歴応答を, 図 9 は 本パンクレスタイヤの時刻歴応答を示している。二つ の図を比較すると,まず応答曲線の第一波の振幅が本 パンクレスタイヤで小さくなっており，また振動の収 束も通常夕イヤでは約 $1.1 \mathrm{~s}$ 程度かかっているのに対 し, 本パンクレスタイヤでは, $0.75 \mathrm{~s}$ 程度で収束して

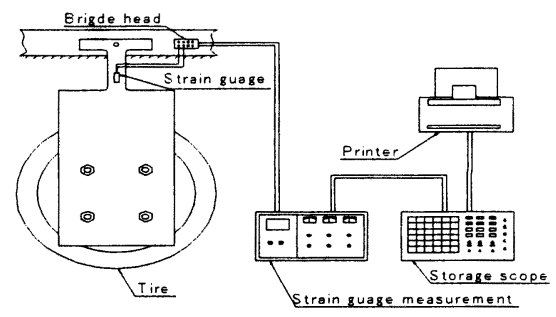

Fig. 7 Experimental set up of the vibration systemcarrying the tire
いる.すなわち, パンクレス化によりタイヤの取付け られた系の振動減衰を大きくできることがわかる。こ のときの基本固有振動数は約 $10 \mathrm{~Hz}$ であり, タイヤの 固有振動数の約 $1 / 8$ 程度である.

$4 \cdot 2$ 振動伝達率本実験における衝撃力は下記 のようにして計算できる，すなわち，鋼球落下時の夕 イヤに与える衝撃力は運動量保存の法則より

$$
m v=\int_{t_{1}}^{t_{2}} F \mathrm{~d} t
$$

となる。ここに, $m$ は鉄球の質量, $v$ は夕イヤに鉄球 が当たる瞬間の速度， $F$ は夕イヤに当たる衝撃力であ り $t$ は時間である. 夕イヤ表面に当たるときの速度は $v=\sqrt{2 g h}$ である.ここに, $g$ は重力加速度であり, $h$ は落下高さである. 鉄球が夕イヤに当たると, タイヤ が変形し系の基本周期の $1 / 4$ で鋼球の速度は零とな る.したがって,

$$
m \sqrt{2 g h}=\int_{0}^{\tau / 4} F \mathrm{~d} t
$$

$0 \sim \tau / 4$ の間の平均衝撃力 $F$ は上式より次のように求 められる。

$$
F=4 m \sqrt{2 g h} / \tau
$$

本実験における鉄球の質量は $m=0.108 \mathrm{~kg}$, 落下高 さは $h=0.81 \mathrm{~m}$ である.また, 基本周期は $\tau=0.1 \mathrm{~s}$ であるので, これらを式 (19)に代入すると平均衝撃力

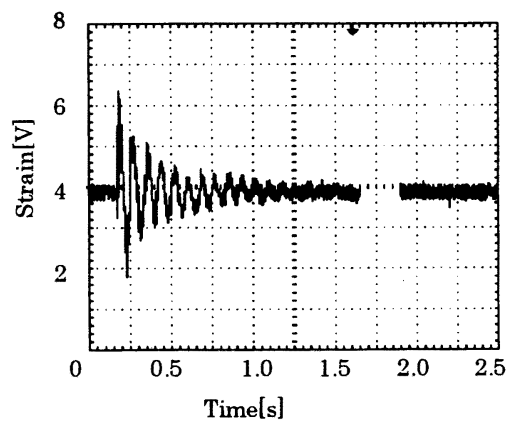

Fig. 8 Response of a normal tire

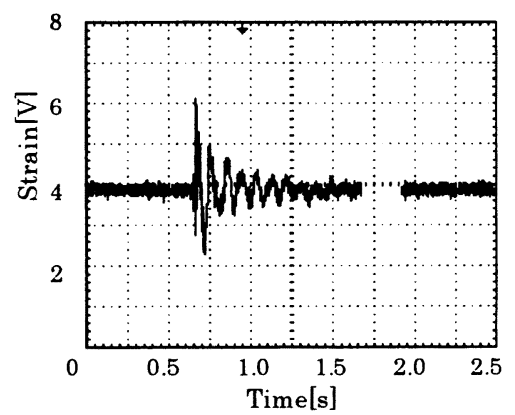

Fig. 9 Response of our tire 


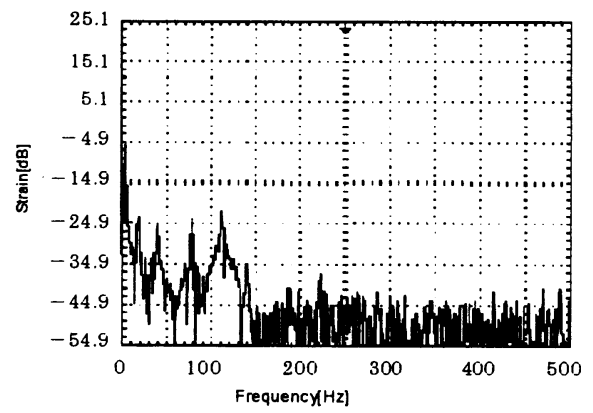

Fig. 10 FFT analysis for the normal tire under the impulse load

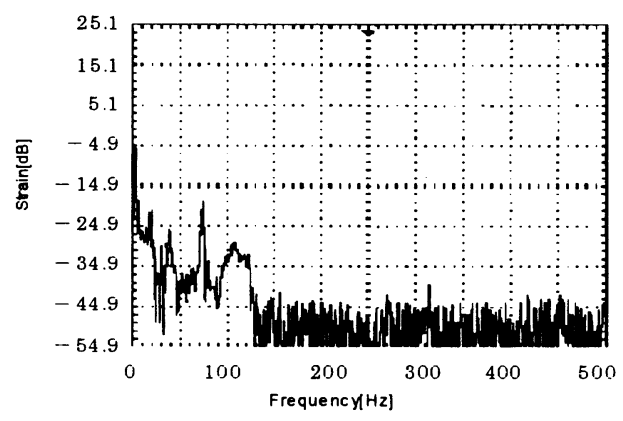

Fig. 11 FFT analysis for our tire under the impulse load

は $F=17.2 \mathrm{~N}$ と求まる. 式(19)と図 8 および図 9 よ り, 鉄球の衝突によりホイールに作用する荷重は通常 タイヤで $P=4.6 \mathrm{~N}$, 本パンクレスタイヤで $P=4.03$ $\mathrm{N}$ となっている.したがって, 衝撃による最大伝達率 $T=P / F$ は, 通常夕イヤでは近似的に $T=0.27$, 本パ ンクレスタイヤで $T=0.23$ となる.このときの通常 タイヤに比べて本タイヤの振動伝達率の低減率は約 15\%となっており, 本夕イヤの使用で突起乗越し時の 振動低隇ができることがわかる.

$4 \cdot 3$ 高次振動の影響図 10 および図 11 は上記 応答のFFT 分析を行った結果である. 本結果では, ひずみゲージょり得られる電圧の $1 \mathrm{~V}(\mathrm{rms})$ が $0 \mathrm{~dB}$ としている. 本実験のタイヤは, 前述の Bohmの夕 イヤに比べタイヤ内圧が 2 倍以上と大きいので, 第一 次の振動数は前記の計算值以上と思われる。したがっ て, $110 \mathrm{~Hz}$ 近傍に現れたピークがタイヤの一次振動 に対応し, それ以下は構造系の振動が支配的と思われ る.

通常タイヤと本パンクレスタイヤを比較したとき, $100 \sim 130 \mathrm{~Hz}$ における本夕イヤのピークが小さくなっ ており,また, 200〜 $300 \mathrm{~Hz}$ 近傍の周波数でも振動振 幅が小さくなっていることが認められる。この差は一
見計測誤差のようにも見えるが, 数回の実験で同じ傾 向の結果が得られており計測誤差とは考えずらいこと から, 本夕イヤを使用することでロードノイズも低減 できていると考えられる. なお, シーラント層は遠心 力により変形するが, 本シーラント層はゴム状の固体 であるのでそのつぶれは小さく, かつ偏りも発生しな い構造であるので, 遠心力による影響は張力の変化に よる固有振動数の増加としては現れるが, 応答振幅と しては本解析より若干小さくなるので，いずれも安全 側に作用すると思われる.

\section{5. 結言}

本研究では自己修復タイヤの新しいシーラント層を 開発し，その性能試験を行った。また，本タイヤを有 する振動特性を解析および実験の両面より検討した。 その内容を要約すると

（1）本研究では前研究のシーラント層の自己修復 性能を落とすことなく，タイヤの製造過程に組込みや すい複合格子シーラント層を新たに開発した。

（2）吸水性高分子であるポリマを含むシーラント 層により, 振動減衰を大きくできることを明らかにし た。

（3）本タイヤを使用することで, 最大振動伝達率 を小さくすることができ, 通常タイヤに比べて突起乗 越し時の振動も低減できた。

\section{付 録}

式 ( 5 )の解マトリックスの要素は下記のようであ る.

$$
\begin{aligned}
& b_{11}=1, \quad b_{12}=\phi, \quad b_{13}=\cos \phi \\
& b_{14}=(\sin \alpha \phi)(1-i \eta) /\left(1+\eta^{2}\right) \\
& b_{15}=(\cos \beta \phi)(1-i \eta) /\left(1+\eta^{2}\right) \\
& b_{16}=(\sin \beta \phi)(1-i \eta) /\left(1+\eta^{2}\right), \quad b_{17}=0 \\
& b_{21}=0, \quad b_{22}=1, \quad b_{23}=-\gamma_{1} \sin \alpha \phi \\
& b_{24}=\left(\gamma_{1} \cos \alpha \phi\right)(1-i \eta) /\left(1+\eta^{2}\right) \\
& b_{25}=\left(-\gamma_{2} \sin \beta \phi\right)(1-i \eta) /\left(1+\eta^{2}\right) \\
& b_{26}=\left(\gamma_{2} \cos \beta \phi\right)(1-i \eta) /\left(1+\eta^{2}\right), \quad b_{27}=0 \\
& b_{31}=1 / \delta, \quad b_{32}=\phi / \delta \\
& b_{33}=\left[\left(1-\gamma_{1} \alpha\right) \cos \alpha \phi\right] / \delta \\
& b_{34}=\left[\left(1-\gamma_{1} \alpha\right) \sin \alpha \phi\right](1-i \eta) /\left[\delta\left(1+\eta^{2}\right)\right] \\
& b_{35}=\left[\left(1-\gamma_{2} \beta\right) \cos \beta \phi\right](1-i \eta) /\left[\delta\left(1+\eta^{2}\right)\right] \\
& b_{36}=\left[\left(1-\gamma_{2} \beta\right) \sin \beta \phi\right](1-i \eta) /\left[\delta\left(1+\eta^{2}\right)\right] \\
& b_{37}=0, \quad b_{41}=0, \quad b_{42}=0 \\
& b_{43}=\left[S^{2}\left(\gamma_{1}-\alpha\right) \sin \alpha \phi\right](1+i \eta) / \delta \\
& b_{44}=\left[S^{2}\left(\alpha-\gamma_{1}\right) \cos \alpha \phi\right] / \delta^{3} \\
& b_{45}=\left[S^{2}\left(\gamma_{2}-\beta\right) \sin \beta \phi\right] / \delta^{3}
\end{aligned}
$$


$b_{46}=\left[S^{2}\left(\beta-\gamma_{2}\right) \cos \beta \phi\right] / \delta^{3}, \quad b_{47}=0, \quad b_{51}=0$

$b_{52}=0, \quad b_{53}=\left[S^{2} \alpha\left(\gamma_{1}-\alpha\right) \cos \alpha \phi\right](1+i \eta) / \delta^{3}$

$b_{54}=\left[S^{2} \alpha\left(\gamma_{1}-\alpha\right) \sin \alpha \phi\right] / \delta^{3}$

$b_{55}=\left[S^{2} \beta\left(\gamma_{2}-\beta\right) \cos \beta \phi\right] / \delta^{3}$

$b_{56}=\left[S^{2} \beta\left(\gamma_{2}-\beta\right) \sin \beta \phi\right] / \delta^{3}, \quad b_{57}=0, \quad b_{61}=0$

$b_{62}=(1+i \eta) / \delta^{2}$

$b_{63}=(1+i \eta)\left[\left(\gamma_{1} \alpha^{2}-\alpha\right) \sin \alpha \phi\right] / \delta^{2}$

$b_{64}=\left[\left(\alpha-\gamma_{1} \alpha^{2}\right) \cos \alpha \phi\right] / \delta^{2}$

$b_{65}=\left[\left(\gamma^{2} \beta^{2}-\beta\right) \sin \beta \phi\right] / \delta^{2}$

$b_{66}=\left[\left(\beta-\gamma_{2} \beta^{2}\right) \cos \beta \phi\right] / \delta^{2}, \quad b_{67}=0$

$b_{71}=b_{72}=b_{73}=b_{74}=b_{75}=b_{76}=0, \quad b_{77}=1$

ここに

$$
\begin{aligned}
\alpha & =\left\{1+0.5 T_{0}^{*}\left(1+S^{2}\right)\right. \\
& \left.+\sqrt{\left[1+0.5 T_{0}^{*}\left(1+S^{2}\right)\right]^{2}-1}\right\}^{1 / 2} \\
\beta & =\left\{1+0.5 T_{0}^{*}\left(1+S^{2}\right)\right. \\
& \left.-\sqrt{\left[1+0.5 T_{0}^{*}\left(1+S^{2}\right)\right]^{2}-1}\right\}^{1 / 2} \\
\gamma_{1} & =\frac{\left(1+S^{2}\right) \alpha}{\alpha^{2}+S^{2}}, \quad \gamma_{2}=\frac{\left(1+S^{2}\right) \beta}{\beta^{2}+S^{2}} \\
S^{2} & =A R^{2} / I_{y}=S_{0}^{2} \delta^{2} \\
S_{0} & =A R_{0}^{2} / I_{y}, \quad \delta=R / R_{0}
\end{aligned}
$$

\section{文献}

(1) Grossmann, R., Quartz Crystals as Remote Sensors for
Tire Pressure, IEEE Transactions on Instrumentation and Measurement Technology, Vol. 16, No. 13 (1999), pp. 1745-1749.

(2) Bradley, J. et al., Design of Emergency Tire Inflation System for Long Haul Trucks, SAE Technical Paper (Society of Automotive Engineers), SAE-952952 (1995), p. 4.

(3) Yamagiwa, T. et al., Development of Puncture Resistance Tire Tube, Preprint of Society of Automotive Engineers of Japan, No. 976 (1997), pp. 279-282.

(4) HONDA NO NIRIN GIJYUTU, ATARASHII BOUSIEKI NO KOUKA, Car and Maintenance, Vol. 51, No. 1 (1997), pp. 40-41.

(5) Nagaya, K. et al., Tire with Self-Repairing Mechanism, Transactions of the Japan Society of Mechanical Engineers, Series C, Vol. 71, No. 708 (2005), pp. 26352642.

(6) Bohm, Von F., Mechanik des Gurtelrefens, IngenieurArchiv, Vol. XXXV (1966), pp. 82-101.

(7) Yoshimura, S., On the Vibration Properties of Tires, Journal of the Society of Rubber Industry, Vol. 61, No. 1 (1988), pp. 19-29, Japan.

(8) Adachi, Z., Vibration Characteristics of Tire, Journal of Society of Automotive Engineers of Japan, Vol. 38, No. 12 (1984), pp. 1457-1462.

(9) Fukuoka, N., Vibration Characteristics of Tires, Journal of Society of Automotive Engineers of Japan, Vol. 30, No. 3 (1976), pp. 196-202. 